\title{
Trypanocidal Activity of Traditional Antiparasitic Medicinal Plants from the Amazon
}

\author{
María-Helena Arias' , Gustavo A. Vallejo², Giovanny Garavito ${ }^{3, *}$
}

\section{María-Helena Arias ${ }^{1}$, Gustavo A. Vallejo, Giovanny Garavito ${ }^{1, *}$}

'Universidad Nacional de Colombia, Sede Bogotá, Facultad de Ciencias, Departamento de Farmacia, Grupo de Investigación FaMeTra (Farmacología de la Medicina Tradicionaly Popular); Carrera 30 45-03, Bogotá D.C. 111321, COLOMBIA.

'2 Laboratorio de Investigación en Parasitología Tropical, Facultad de Ciencias, Universidad del Tolima, Ibagué, COLOMBIA.

\section{Correspondence}

\section{Giovanny Garavito}

Carrera 30 No. 45-03 Facultad de Ciencias, Edificio 450. Bogotá, Colombia.

Tel.: +573003217098

E-mail address: ggaravitoc@unal.edu.co

\section{History}

- Submission Date: 18-05-2021.

- Review completed: 04-06-2021;

- Accepted Date: 01-07-2021

DOI : $10.5530 /$ pres.13.4.15

Article Available online

http://www.phcogres.com

\section{Copyright}

(C) 2021 Phcog.Net. This is an openaccess article distributed under the terms of the Creative Commons Attribution 4.0 International license.

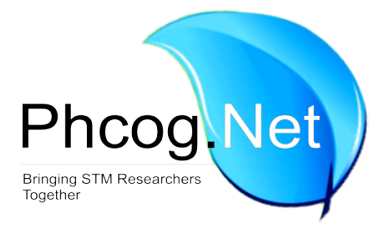

\begin{abstract}
Background: Neglected Infectious Diseases control is an urgent need in endemic areas, but it's not a priority in the commercial interests of the pharmaceutical industry. Chagas disease (caused by Trypanosoma cruzl) is the parasitic disease of greatest impact in Latin America. Medicinal plants continue to be an affordable front-line option in endemic areas. Thus, we aimed to advance in the pharmacological evaluation of four medicinal plants traditionally used in the Amazon against parasitic infections. Materials and Methods: The plants were collected in the Amazon region of Colombia. The dry plant material was submitted to water percolation extraction. Extracts were tested in vitro against Trypanosoma cruzi (epimastigotes), and cytotoxicity was assessed against HepG2 and MRC5 cells. Finally, the general profile of metabolites present in the extracts was studied by thin-layer chromatography. Results: In vitro, against T. cruzi, extracts of Ambelania duckei and Curarea toxicofera shows concentration-dependent inhibition $\left(\mathrm{IC}_{50}\right.$ of $221+/-29$ and $50+/-5 \mu \mathrm{g} / \mathrm{mL}$ respectively), comparable with benznidazole $\left(\mathrm{IC}_{50}: 0.7 \mathrm{\mu g} / \mathrm{mL}\right)$; while Abuta grandifolia and Aspidosperma excelsum exhibited $\mathrm{IC}_{50}$ 's $>500 \mathrm{\mu g} / \mathrm{mL}$. All extracts showed no cytotoxicity against HepG2 and MRC5 cells. Yields of extraction were between 3.2 and $9.5 \%$ and preliminary phytochemical profile showed flavonoids and steroids in all extracts. Conclusion: Promising plants, traditionally used to treat other protozoan infections, could be assessed against $T$. cruzi. C. toxicofera exhibits good activity against epimastigotes of T. cruzi, being a species that can reasonably be considered for bioassay-guided antitrypanosomal fractionation.

Key words: Medicinal plants, Trypanocidal agents, Neglected Infectious Diseases, Trypanosoma cruzi, Chagas disease, Cytotoxicity.

Key Messages: Since knowledge, uses and attitudes towards Chagas disease are generally absent, it is not easy to find useful plants to treat this disease, directly in traditional knowledge. Plants studied against other protozoa or those used by indigenous people to treat other protozoa infections, could be assessed against T. cruzi.
\end{abstract}

\section{INTRODUCTION}

Control and elimination of Neglected Infectious Diseases (NID) is fundamental to the achievement of several of the Sustainable Development Goals (SDG), proposed by the United Nations Development Program (UNDP); aimed at eradicating poverty, protecting the planet and promoting peace and prosperity for all people, ${ }^{[1]}$ by 2013 , half of low- and middle-income countries received less than US\$ 0.35 per person for drug and vaccine care and research for NIDs and other emerging diseases, so it is not surprising that of the 1559 drugs approved between 1975 and 2004, only 21 were for NID treatment. ${ }^{[2,3]}$ In recent years, the fight against parasitic diseases has focused on strategies to optimize existing therapies, the use of combination therapies, the reuse of drugs in other indications, and/ or the use of natural products. ${ }^{[2,4-7]}$

Chagas disease (caused by Trypanosoma cruzi) is the parasitic disease of greatest impact in Latin America, nearly 90 million people in 19 endemic countries are at risk of contracting the disease and 16 million people are already infected although, in recent years, there has been an increase in the number of infected persons in Canada, the United States, and Europe. ${ }^{[3,5,8]}$ There are only two drugs available for treatment (benznidazole and nifurtimox) and, their use is limited by difficulties in administering the treatment, side effects, genotoxicity, and the impossibility of using it in patients with psychiatric, neurological, renal or hepatic disorders. ${ }^{[7,9,10]}$ Since initial or acute symptoms of Chagas disease are evident only in $10 \%$ of infected people, and generally confused with other pathologies, knowledge, uses and attitudes towards the disease are generally absent. Consequently, it is not easy to find useful plants to treat this disease, directly in traditional knowledge.

Medicinal plants are first-line therapy in endemic areas (used by $25-75 \%$ of people). ${ }^{[11]}$ The use of bark of Chichona (Cinchona officinalis L.) by the aborigines of South America was profited by Europeans for the discovery of quinine, in the 19th century, from which derivatives such as chloroquine, amodiaquine, primaquine, and mefloquine have

Cite this article: Arias M, Vallejo GA, Garavito G. Trypanocidal Activity of Traditional Antiparasitic Medicinal Plants from the Amazon. Pharmacog Res. 2021;13(4):227-32. 
been synthesized. ${ }^{[12]}$ The traditional Chinese herbal remedy qinghāo (Artemisia annua L.), used since ancient times for the treatment of intermittent fevers, ${ }^{[12]}$ allowed to isolate artemisinin and synthesized derivatives widely used today for the treatment of malaria.

Healing plants are a source of promising compounds with antiparasitic activity; in Colombia good to moderate activity was reported in twentyone extracts of plants of the family Annonaceae, against Trypanosoma sp., Leishmania sp., Plasmodium sp., ${ }^{[13]}$ and more recently in Japan, extracts of Rhus succedanea (seeds), Cinnamomum daphnoides (fruits) and Styrax japonica (fruits) showed antiparasitic activity against T. b. rhodesiense, T. cruzi, L. donovani, and P. falciparum with $\mathrm{IC}_{50}<$ $20 \mu \mathrm{g} / \mathrm{mL},{ }^{[14]}$ the previous examples allow to recognize that extracts of medicinal plants with promising activity against Plasmodium have similar activity against other protozoan parasites. We previously studied the use of plants to treat parasitic diseases in a Uitoto (Ziora Amena) community of the Amazonas region of Colombia. ${ }^{[15]}$

Abuta grandifolia (Mart.) Sandwith is jungle brush of approximately $1.5 \mathrm{~m}$ high, smooth leafs with three main veins, bitter taste and common name "aifo" (A+fo (uitoto)) or "abuta"; it is used as a traditional remedy in the treatment of malaria and is part of the mixture of the poison "curare".[16,17] The plant is used by natives of the Amazon and Putumayo provinces of Colombia in the form of leaf infusion to treat malarial fevers, it is also used in South America claimed to have many medicinal properties. ${ }^{[18,19]}$ Ambelania duckei Markgr is a jungle wood tree of approximately $20 \mathrm{~m}$ of height, scarce, the bark of bitter flavor which, when scraping, generates sticky exudate of reddish color in little quantity; common name: "Costillo negro", it is used like a traditional remedy in the treatment of malaria and makes part of the mixture of the poison "curare". ${ }^{16]}$ Aspidosperma excelsum Benth, it is a woody tree of $15 \mathrm{~m}$ high, with a $30 \mathrm{~cm}$ diameter ribbed trunk, simple alternate oblong green leaves on the beam and greyish green on the top, of common name: "Costillo blanco", "Remocaspi" (For the use of wood to make the oars, and the quechua "caspi", tree, ${ }^{[20]}$ Gollaveai (uitoto); ${ }^{[16,18]}$ the decoction of bark, drunk, is traditionally used against malaria (Colombia, Peru and Brazil) $)^{[17,18,21,22]}$ or mixed with C. odorata for intestinal infections or external use against herpes. ${ }^{[22]}$ Curarea toxicofera (Wedd.) Barneby \& Krukoff is a jungle liana of approximately $10 \mathrm{~m}$ height and $4 \mathrm{~cm}$ wide, which grows around a smooth trunk tree called "castaño", its leaves are whitish by the underside, of bitter flavor; when cutting the liana, it appears abundant exudate liquid of translucent color; common name: "Bejuco de llaño" (Llaño K+nai (uitoto)) or "oso perezoso" (because lazy bears climbing it). It is traditionally used as a remedy in the treatment of malaria, ${ }^{[15,16]}$ and is part of the "curare" poison mixture. ${ }^{[23]}$

\section{MATERIALS AND METHODS}

\section{Plant collection and extracts preparation}

A. grandifolia - Menispermaceae COL000410190 and COL000413525 (S 4 6' 43" W 69 54' 36") leafs, A. duckei - Apocynaceae COL000413594

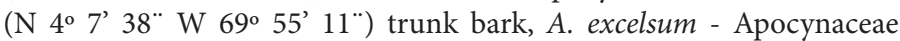
COL000362034 (S 40 7' 52" W 69 55' 37") trunk bark and C. toxicofera - Menispermaceae COL000413526 (S 40 7’ 46” W 69 55’ 14") liana; all Colombian origin, were collected in the municipality of Leticia-Amazon, at estimated height of 117 m.a.s.l. A voucher specimen was deposited at the Colombian National Herbarium. A specialist identified all collected material and the plant name has been checked with The Plant List. ${ }^{[2]}$ This research was carried out under the contract for access to genetic resources and derived products No. 269 of the Ministry of Environment and Sustainable Development of Colombia.

Dried plants were submitted to a percolation extraction process with water as described in the USP pharmacopeia, ${ }^{[25]}$ with some modifications: $100 \mathrm{~g}$ of dried and ground crude material (No. 10 mesh) were moistened with a sufficient amount of extracting solvent for three hours in a well-covered container, ${ }^{[26]}$ then transferred to a percolator where it was macerated for $24 \mathrm{hr}$ and then slowly percolated $(1 \mathrm{~mL} / \mathrm{min})$, until $1000 \mathrm{~mL}$ of percolation is obtained, at which point the drug was practically depleted. ${ }^{[26]}$ The percolation was then filtered and freeze-dried (Labconco Freezone 4.5). All preparations were stored at $4^{\circ} \mathrm{C}$, in an environment protected from daylight, until use.

\section{Chemicals}

Benznidazole ( $N$-Benzyl-2-nitro- $1 H$-imidazole-1-acetamide), resazurin and hemin were purchased from Sigma Aldrich, DMSO (dimethyl sulfoxide) and fetal bovine serum were acquired from Thermo Fisher Scientific. All chemicals provided were of reagent grade.

\section{Parasites}

T. cruzi (Y strain) was kindly donated by Tropical Parasitology Research Laboratory, University of Tolima (Colombia). The trypomastigote forms were obtained from blood samples of mice infected with T. cruzi following the procedure described by Lourenço et al, ${ }^{[27]}$ with some modifications. In vivo infection was performed in Swiss ICR mice of $23 \pm 1 \mathrm{~g}$ infected by intra-peritoneal with approximately $1 \times 10^{5}$ parasites $/ \mathrm{mL}$, 15 days post-infection (at peak of parasitemia), mice were anesthetized and approximately $1 \mathrm{~mL}$ of blood was obtained by cardiac puncture. Blood was centrifuged at $500 \mathrm{~g}$ for $30 \mathrm{~min}$, in a biological safety box, plasma was removed and $5 \mathrm{~mL}$ of liver infusion tryptose culture medium, enriched with $10 \%$ fetal bovine serum and $1 \%$ hemine (LIT+10\%FBS) were added, the sample was centrifuged again and medium removed; then the concentrate of red blood cells and parasites was transferred to a culture tube containing $5 \mathrm{~mL}$ of LIT $+10 \%$ FBS medium, the tube was incubated at $28^{\circ} \mathrm{C}$ and shaken every 2 days until day 10 when parasitic forms and their conversion from trypomastigote to epimastigote were checked under an optical microscope, then the culture medium was changed and incubated until day 15 when the complete conversion from trypomastigote forms to epimastigote was achieved, parasite growth was determined by counting cells using a Neubauer hemocytometer.

\section{In vitro anti-trypanosomal activity}

All treatments were prepared in DMSO, final solvent concentration never exceeding $0.5 \%$. In a 96-well plate were added, in triplicate, $100 \mu \mathrm{L}$ of medium LIT $+10 \%$ FBS containing $1 \times 10^{6}$ epimastigotes $/ \mathrm{mL}$ plus the treatments vehiculated in $100 \mathrm{~mL}$ of medium LIT+10\%FBS (final well volume $200 \mu \mathrm{L}$ ); treatments were: $0.29-300 \mu \mathrm{g} / \mathrm{mL}$ of $C$. toxicofera, 62.5 $500 \mu \mathrm{g} / \mathrm{mL}$ of A. grandifolia, A. excelsum and A. duckei; growth control was the vehicle of treatments (LIT $+10 \% \mathrm{FBS}+\mathrm{DMSO} 0.5 \%)$ and active control benznidazole (BNZ) $0.25-2 \mu \mathrm{g} / \mathrm{mL}$. Plates were incubated at $28^{\circ} \mathrm{C}$ for 6 days. Parasitic viability was determined using the rezarsurine colorimetric method by adding $20 \mu \mathrm{L}$ of $0.44 \mu \mathrm{M}$ solution in each well and incubating for $4 \mathrm{~h}$ at $37^{\circ} \mathrm{C}$. Relative fluorescence units (RFU) were determined in LB 970 Twinkle fluorescence reader (BERTHOLD- Technologies. $\mathrm{GmbH}$ and Co.KG), with $\lambda_{\mathrm{exc}}: 540 \mathrm{~nm}$ and $\lambda_{\mathrm{em}}: 600 \mathrm{~nm}$.

\section{Cytotoxicity}

Cell viability assays were developed using human cancer cell line HepG2 (liver cells) and human non-cancer cell line MRC5 (fetal lung fibroblast cells), seeded in a 96-well flat-bottomed plate (density 150000 cells $/ \mathrm{mL}$ and $100 \mu \mathrm{L} /$ well) and incubated at $37^{\circ} \mathrm{C}$ in a $5 \% \mathrm{CO}_{2}$ environment; RPMI 1640 culture medium supplemented with $10 \%$ fetal bovine serum (heatinactivated) was used. ${ }^{[28,29]}$ The extracts were tested at $6.25-100 \mu \mathrm{g} / \mathrm{mL}$ and cells were cultured for $48 \mathrm{hr}$. Viability was determined using a classical resazurin assay $(0.15 \mathrm{mg} / \mathrm{mL}$ in PBS), plates were incubated for $4 \mathrm{hr}$ and RFU were determined as described above. Experiments 
were performed in triplicate and $\mathrm{CC}_{50}$ (concentration required for the reduction of cell viability by half) was determined.

\section{Statistical analysis}

In vitro concentration-response assays were carried out to obtain 50\% inhibitory and cytotoxic concentrations $\left(\mathrm{IC}_{50}\right.$ and $\left.\mathrm{CC}_{50}\right)$, as a measure of anti-trypanosomal or cytotoxic activity; estimated from concentrationresponse curves by regression analysis using Excel'. In each case, at least two independent determinations were made.

\section{Preliminary phytochemical Analysis}

The general profile of metabolites present in the extracts was evaluated or confirmed by thin-layer chromatography (TLC) on Silicagel 60G $\mathrm{F}_{254}$, using various solvent systems comprising: Toluene/ethyl acetate/diethylamine, Ethyl acetate/acetic acid/methanoic acid/wáter, Ethyl acetate/ methanol/acetic acid (or water), Chloroform/acetic acid/methanol/ water and visible or UV light at 254 and $365 \mathrm{~nm}$, after spraying with different types of reagents (Dragendorff, NP/PEG, Vanillin/H2SO4, Kedde, Anisaldehyde Sulfuric acid). ${ }^{[30]}$

\section{RESULTS}

The percolation extraction of plants led the extraction yields shown in Table 1.

\section{Table 1: Yield of extracts.}

\begin{tabular}{ccccc}
\hline Plant species & $\begin{array}{c}\text { Part } \\
\text { used }\end{array}$ & $\begin{array}{c}\text { Dry weight } \\
\text { (mg Powder) }\end{array}$ & Extract & $\begin{array}{c}\text { Yield }(\% \text { w/w) } \\
\text { of crude } \\
\text { extract }\end{array}$ \\
\hline Abuta grandifolia & Leaf & 100 & Water PE & 5.8 \\
Ambelania duckei & $\begin{array}{c}\text { Trunk } \\
\text { bark }\end{array}$ & 100 & Water PE & 5.5 \\
Aspidosperma & $\begin{array}{c}\text { Trunk } \\
\text { excelsum }\end{array}$ & 100 & Water PE & 3.2 \\
burarea toxicofera & Liana & 100 & Water PE & 9.5 \\
\hline
\end{tabular}

$\mathrm{PE}=$ percolation extraction.

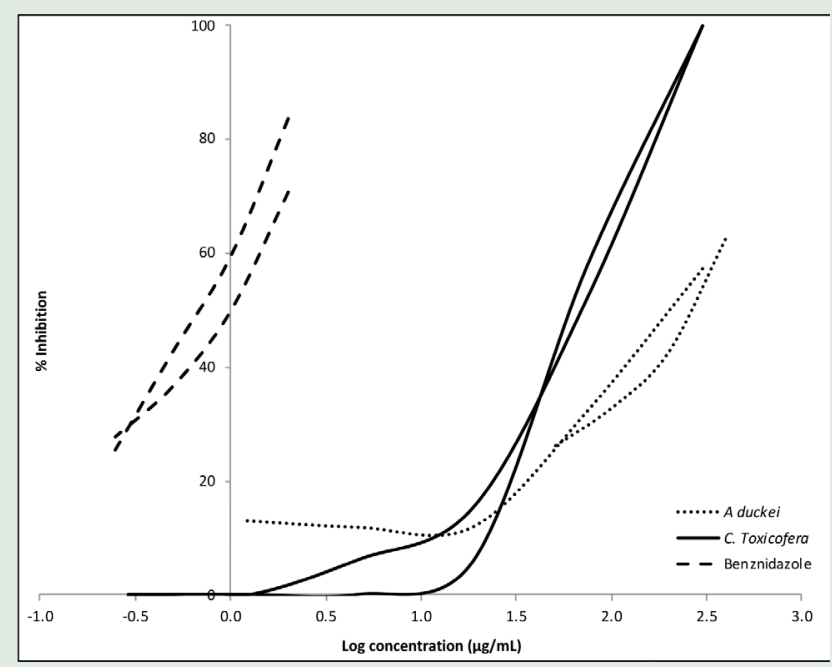

Figure 1: Concentration-dependent anti-trypanosomal activity of Benznidazole (dashed line) and water extracts of Ambelania duckei (dotted line) and Curarea toxicofera (plain line). Each line corresponds to an independent test.
Table 2: In vitro anti-trypanosomal activity $\left(\mathrm{IC}_{50}\right)$ against Trypanosoma cruzi (Y strain), cytotoxicity to HepG2 and MRC5 cells $\left(\mathrm{CC}_{50}\right)$ and selectivity index (SI) of active plants studied.

\begin{tabular}{ccccc}
\hline Samples & $\begin{array}{c}\mathrm{IC}_{50} \\
(\mu \mathrm{g} / \mathrm{mL} \pm \mathrm{SD})\end{array}$ & $\begin{array}{c}\mathrm{HepG} \mathrm{CC}_{50} \\
(\mu \mathrm{g} / \mathrm{mL})\end{array}$ & $\begin{array}{c}\mathrm{MRC5} \mathrm{CC}_{50} \\
(\mu \mathrm{g} / \mathrm{mL})\end{array}$ & $\mathrm{SI}$ \\
\hline Ambelania duckei & $221+/-29$ & $>100$ & $>100$ & $>0.45$ \\
Curarea toxicofera & $50+/-5$ & $>100$ & $\mathrm{ND}$ & $>2$ \\
\hline
\end{tabular}

$\mathrm{IC}_{50}$ Concentration inhibiting $50 \%$ of parasite growth. $\mathrm{CC}_{50}$ Concentration killing $50 \%$ of cells. Data from at least two independent determinations

Table 3: Qualitative phytochemical characteristics of the extracts by thin-layer chromatography.

\begin{tabular}{ccccc}
\hline Phytochemical & $\begin{array}{c}\text { Abuta } \\
\text { grandifolia }\end{array}$ & $\begin{array}{c}\text { Ambelania } \\
\text { duckei }\end{array}$ & $\begin{array}{c}\text { Aspidosperma } \\
\text { excelsum }\end{array}$ & $\begin{array}{c}\text { Curarea } \\
\text { toxicofera }\end{array}$ \\
\hline Alkaloids & + & - & + & + \\
Flavonoids & + & + & + & + \\
Steroids & + & + & + & + \\
Cardiac & & - & & - \\
glycosides & & & & - \\
Saponins & - & - & - & - \\
\hline
\end{tabular}

(+) presence, (-) absence.

\section{In vitro anti-trypanosomal activity}

Against T. cruzi, extracts of $A$. duckei and C. toxicofera shows concentration-dependent inhibition (Figure 1), with $\mathrm{IC}_{50}$ of $221+/-29 \mu \mathrm{g} / \mathrm{mL}$ and $50+/-5 \mu \mathrm{g} / \mathrm{mL}$ respectively; while active control BNZ showed an $\mathrm{IC}_{50}$ of $0.7+/-0.1 \mu \mathrm{g} / \mathrm{mL}$. A. grandifolia and A. excelsum exhibited $\mathrm{IC}_{50}$ 's $>500 \mu \mathrm{g} / \mathrm{mL}$ (maximum concentration assessed).

\section{Cytotoxicity}

None of the A. grandifolia, A. duckei, A. excelsum and C. toxicofera extracts showed cytotoxicity at concentrations $\leq 100 \mu \mathrm{g} / \mathrm{mL}$, on HepG2 or MRC5 cell lines. An initial estimate of the selectivity index of active species is shown in Table 2.

\section{Preliminary phytochemical Analysis}

Phytochemical screening revealed the presence of flavonoids and steroids and the absence of saponins (Table 3 ).

\section{DISCUSSION}

Chagas disease is among the 17 most important neglected tropical diseases for which there is no effective vaccine, so transmission control is based on prevention (i.e. vector control and drug prophylaxis), veterinary care of infected animals, reservoir control and improvements in housing, water and basic sanitation; however, despite achievements in decreasing the number of cases and screening in blood banks to reduce the risk of infections from blood transfusions, there is a need for improved diagnosis, access to treatment and research leading to the development of drugs that can treat the disease in its early and chronic stages, effectively and with reduced toxicity. ${ }^{[31]}$ Natural products maintain a leading role as a source of new drugs, of 1010 new active substances approved as medicines by regulatory agencies over the last 25 years, 490 (48.5\%) are of natural origin. ${ }^{[8]}$ Current trypanosomiasis chemotherapy is unsatisfactory because of its unacceptable toxicity, low efficacy, undesirable course of administration and drug resistance.

Several medicinal plants show trypanocidal activity against different parasitic stages (epimastigotes, trypomastigotes and amastigotes), being 
epimastigotes form the most used since it offers as main advantages a higher susceptibility to the action of the assessed substances and easy cultivation in laboratory, resulting in a particularly useful pharmacological model for screening of plant extracts which can later be evaluated against other parasitic forms. ${ }^{[32]}$ Medicinal plant compounds have demonstrated greater chemical diversity, lower susceptibility to the development of resistance (since the activity in the plant often depends on the synergy of several different molecules), lower toxicity and innovative mechanisms of action.

Infected people are often unaware of their condition or misdiagnose it, because the symptoms are easily confused with other pathologies, thus traditional knowledge about Chagas disease is not common. Therefore, many plants that have been studied for their effects against T. cruzi are the same ones that have shown effects against other protozoa in laboratory testing or those that are used by indigenous people to treat other protozoa infections, such as leishmaniasis, sleeping sickness and malaria. ${ }^{[32]}$ Percolation extraction in water was selected, as it is the most similar method to the traditional use ${ }^{[33]}$ and in a previous work this technique was selected according to practical, convenient and reproducible criteria; showing for C. toxicofera, a better extraction performance compared to continuous distillation and traditional preparation. ${ }^{[26]}$ The highest extraction yield was achieved with $C$. toxicofera, a result similar to previous work $\left(8.9 \%{ }^{[26]}\right)$ followed by intermediate yields obtained for A. grandifolia and $A$. duckei and the lowest yield was obtained for the trunk bark of $A$. excelsum.

The antiparasitic activity of extracts was classified according to the criteria shown in Table 4. A. duckei's $\mathrm{IC}_{50}$ is considerably higher than the active control Benznidazole (three orders of magnitude) whereas C. Toxicofera's $\mathrm{IC}_{50}$ is two orders of magnitude higher than active control; interesting result considering the great challenge for a primary extract to be compared with an isolated active substance. There was no evidence of selective activity (against cancer cell line), or any cytotoxic activity, in these plants.

A. grandifolia exhibits synonyms such as Abuta concolor Poepp. and Endl, Abuta guianensis Eichler, Anelasma concolor (Poepp. \& Endl.) Miers, Anelasma gardnerianum Miers, Anelasma guianense Miers, Anelasma laurifolium Sagot ex Benth, Anelasma laurifolium Miers, Anelasma laurifolium Sagot ex Diels, Anelasma martianum Miers, Anelasma pallidum Miers, Anelasma spruceanum Miers ex Benth, Anelasma spruceanum Miers, Cocculus grandifolius Mart, Cocculus laevigatus Mart, Trichoa concolor Endl and Trichoa guyanensis Klotzsch \& Eichler. ${ }^{[24]}$ Previously our team showed that ethanolic extract of A. grandifolia leaves (crude alkaloid extract and traditional Huitoto remedy) has good antiplasmodial activity against Plasmodium falciparum $\mathrm{FCB} 2\left(\mathrm{IC}_{50}<1 \mu \mathrm{g} / \mathrm{mL}\right.$ and $27 \mu \mathrm{g} / \mathrm{mL}$ respectively) and antimalarial activity in vivo against

Table 4: Proposed thresholds for in vitro epimastigoticide activity of anti-trypanosomal crude extracts.

\begin{tabular}{cc}
\hline $\mathrm{IC}_{50}(\mu \mathrm{g} / \mathrm{mL})$ & Level of Activity \\
\hline$<50$ & Very good \\
$50-100$ & Good \\
& Good to moderate \\
$101-150$ & This range may reasonably be considered for bioassay-guided \\
& fractionation \\
$151-250$ & Weak \\
$251-350$ & Very weak \\
$>350$ & Inactive \\
\hline
\end{tabular}

$\mathrm{IC}_{50}$ Concentration inhibiting $50 \%$ of parasite growth.
Plasmodium berghei ANKA (66 \% inhibition at $250 \mathrm{mg} / \mathrm{kg} /$ day) ${ }^{[18,19]}$ dichloromethane extract from leaves showed high larvicidal activity against Aedes aegypti larvae ${ }^{[34]}$ and ethanolic extract from the bark showed antimicrobial activity in vitro. ${ }^{[35]}$ A. grandifolia do not show in vitro activity against $T$. cruzi epimastigotes, also, there was no evidence of cytotoxicity on HepG2 and MRC5 cells; qualitatively was detected the presence of alkaloids, flavonoids and steroids in the extract.

A. duckei has no registered synonyms; ${ }^{[24]}$ it shows a weak anti-trypanosomal activity and no selective action (against cancer cell line), or any cytotoxicity, at concentrations $\leq 100 \mu \mathrm{g} / \mathrm{mL}$. The qualitative phytochemical analysis shows the presence of flavonoids, steroids and polyphenols in the extract.

A. excelsum presents synonyms such as Aspidosperma marcgravianum Woodson and Macaglia excelsa (Benth.) Kuntze, ${ }^{[24]}$ plant has been reported as active against Gram-positive cocci, ${ }^{[22]}$ the hydroethanolic extract from trunk bark showed activity against chloroquine-resistant P. falciparum (W2: $\mathrm{IC}_{50} 23.6 \mu \mathrm{g} / \mathrm{mL}$ and $\mathrm{FCB}-2: \mathrm{IC}_{50} 36.0 \mu \mathrm{g} / \mathrm{mL}$ ) and low cytotoxicity $\left(\mathrm{CC}_{50}>250 \mu \mathrm{g} / \mathrm{mL}\right.$ HepG2 cells), also were identified more than 20 different indole alkaloids. ${ }^{[18,21]}$ This plant does not show, under our test conditions, activity against $T$. cruzi epimastigotes and no cytotoxicity $\left(\mathrm{CC}_{50}>100 \mu \mathrm{g} / \mathrm{mL}\right.$, on HepG2 or MRC5 cells) as previously reported for HepG2 cells. Qualitative thin-layer chromatography shows the presence of flavonoids, steroids and alkaloids (as previously reported by do Nascimento ${ }^{[21]}$ ).

C. toxicofera, a climbing vine native to meso and South America, exhibits synonyms such as: Abuta boliviana Rusby, Chondrodendron bioccai Lusina, Chondrodendron polyanthum (Diels) Diels, Cocculus toxicoferus Wedd, Hyperbaena polyantha Diels and Chondrodendron toxicoferum (Wedd.) Krukoff \& Moldenke. ${ }^{[15,24]}$ The plant is used alone or in combination with prescription drugs to prevent and treat malaria in the Colombian Amazon; traditional remedy showed an $\mathrm{IC}_{50}$ of $7.3 \mu \mathrm{g} / \mathrm{mL}$ on Plasmodium falciparum FCR3 and on Plasmodium berghei rodent malaria the $\mathrm{ED}_{50}$ was $328.6 \mathrm{mg} / \mathrm{kg} /$ day. ${ }^{[15]}$ C. Toxicofera exhibits good concentration-dependent anti-trypanosomal activity against epimastigotes of T. cruzi, being considered a species that may reasonably be considered for bioassay-guided fractionation; under our test conditions, the species does not exhibit cytotoxicity at concentrations $\leq 100 \mu \mathrm{g} / \mathrm{mL}$, on HepG2 or MRC5 cells, the selectivity index is $>2$ making its use promising for the treatment of the disease. The phytochemical analysis shows the presence of alkaloids, flavonoids, steroids and polyphenol, coincident with previously reported for this plant. ${ }^{[26]}$

Protozoan parasites (with few exceptions) require salvage pathways for purine synthesis, e.g: adenine phosphoribosyl transferase (common for P. falciparum, B. divergens, T. brucei, T. congolense, T. cruzi, and T. vivax), and hypoxanthine-guanine phosphoribosyl transferase (common for $B$. divergens, $T$. brucei and $T$. cruzi). ${ }^{[36,37]}$ These examples make it conceivable to consider drugs act in one or more biochemical or physiological processes, common to different protozoa, as the key to their antiparasitic activity on different species and, also the existing differences between the pathogen and the host allow the action on the microorganism without producing toxic effects on the host.

\section{CONCLUSION}

Curarea toxicofera exhibits good activity against epimastigotes of T. cruzi, being considered a species that may reasonably be considered for anti-trypanosomal bioassay-guided fractionation. Promising plants, traditionally and popularly used to treat other protozoan infections, could be assessed against $T$ cruzi, as traditional knowledge about the disease is not easy to obtain (because infected people are often unaware of their condition or misdiagnose it). Despite Ambelania duckei showed a weak anti-trypanosomal activity, it should be studied against other 
stages of $T$ cruzi. The extracts of A. grandifolia, A. duckei, A. excelsum and $C$. toxicofera showed no selective activity (against cancer cell line HepG2), or any cytotoxic activity against MRC5 cells.

\section{ACKNOWLEDGEMENT}

$\mathrm{MH}$ Arias is grateful to Departamento Administrativo de Ciencia, Tecnología e Innovación (Colciencias) for their PhD scholarship (Convocatoria 647, Doctorados Nacionales 2014).

\section{CONFLICTS OF INTEREST}

The authors declare no conflict of interest.

\section{ABBREVIATIONS}

A. duckei: Ambelania duckei, A. excelsum: Aspidosperma excelsum; A. grandifolia: Abuta grandifolia; BNZ: benznidazole; $\mathbf{C C}_{50}$ : $50 \%$ cytotoxic concentration; C. toxicofera: Curarea toxicofera; DMSO: dimethyl sulfoxide; FBS: Fetal Bovine Serum; LIT: Liver infusion tryptose medium, $\mathrm{IC}_{50}: 50 \%$ inhibitory concentration; NID: Neglected Infectious Diseases, RFU: Relative fluorescence units; SDG: Sustainable Development Goals; T. cruzi: Trypanosoma cruzi; TLC: thin-layer chromatography; UNDP: United Nations Development Program.

\section{REFERENCES}

1. Undp.org [homepage on the Internet]. United Nations Development Program (UNDP). The Sustainable Development Goals (SDG) 2016. Available from: http:// www.undp.org/content/undp/es/home/sustainable-development-goals.html

2. Kaneko T. Drugs for neglected diseases: part I. Future Med Chem. 2011;3(10):1235-7.

3. Who.int [homepage on the Internet]. World Health Organization (WHO). World malaria report 2017. Available from: https://www.who.int/malaria/publications/ world-malaria-report-2017/en/

4. Monzote L, Siddiq A. Drug Development to Protozoan Diseases. Open Med Chem J. 2011;5:1-3.

5. Paho.org [homepage on the Internet]. Organización Panamericana de la Salud (OPS). Enfermedades Infecciosas Desatendidas en las Américas. 2016. Available from: http://www.paho.org/hq/index.php?option=com_content\&view=article\&i $d=12406 \% 3$ Aneglected-infectious-diseases-americas-success-stories-innovation-reach-neediest\&catid=8876\%3Apublications\&ltemid=42097\&lang=es

6. Who.int [homepage on the Internet]. World Health Organization (WHO). Working to overcome the global impact of neglected tropical diseases: first WHO report on neglected tropical diseases. Available from: https://www.who.int/neglected_diseases/resources/9789241564090/en/

7. Zofou D, Nyasa RB, Nsagha DS, Ntie-Kang F, Meriki HD, Assob JCN, et al. Control of malaria and other vector-borne protozoan diseases in the tropics: enduring challenges despite considerable progress and achievements. Infect Dis Poverty. 2014;3(1):1-14.

8. Castaño Osorio JC, Giraldo García AM. Antiparasitic phytotherapy perspectives, scope and current development. Infectio. 2019;23(2):189

9. Chatelain E. Chagas disease research and development: Is there light at the end of the tunnel? Comput Struct Biotechnol J. 2017;15:98-103.

10. Tarleton RL. Chagas Disease: A Solvable Problem, Ignored. Trends Mol Med. 2016;22(10):835-8

11. Teng WC, Kiat HH, Suwanarusk R, Koh HL. Medicinal plants and malaria: applications, trends, and prospects. Boca Raton: CRC Press, Taylor \& Francis Group; 2016. 472 p

12. Graz B, Kitua AY, Malebo HM. To what extent can traditional medicine contribute a complementary or alternative solution to malaria control programmes? Malar J. 2011;10(S1):S6.

13. Osorio E, Arango GJ, Jiménez N, Alzate F, Ruiz G, Gutiérrez D, et al. Antiprotozoal and cytotoxic activities in vitro of Colombian Annonaceae. J Ethnopharmacol.
2007; 111(3):630-5.

14. Tasdemir D, Maclntosh AJJ, Stergiou P, Kaiser M, Mansour NR, Bickle $\mathrm{O}$ et al. Antiprotozoal and antihelminthic properties of plants ingested by wild Japanese macaques (Macaca fuscata yakui) in Yakushima Island. J Ethnopharmacol. 2020;247:112270.

15. Rodríguez YV, Arias MH, García JO, Deharo E, Garavito G. Pharmacological activity of Curarea toxicofera in combination with classical antimalarial treatments. J Ethnopharmacol. 2018;222:288-94.

16. Biovirtual.unal.edu.co [homepage on the Internet]. Universidad Nacional de Colombia. Colecciones en Línea. Available from: http://www.biovirtual.unal.edu.co

17. Pérez D. Etnobotánica medicinal y biocidas para malaria en la región Ucayali. Folia Amaz. 2006;13(1-2):87

18. Bdigital.unal.edu.co [homepage on the Internet]. Cardenas P. Evaluación de la actividad antimalárica de preparaciones tradicionales obtenidas de dos especies promisorias usadas por una comunidad en zona endémica y profundización en el estudio de su actividad farmacológica. 2011. Available from: http://www.bdigital.unal.edu.co/4173/

19. Garavito G, Rincón J, Arteaga L, Hata Y, Bourdy G, Gimenez A, et al. Antimalarial activity of some Colombian medicinal plants. J Ethnopharmacol. 2006;107(3):460-2.

20. biovirtual.unal.edu.co [homepage on the Internet]. Bernal R., Galeano G. Rodríguez A., Rodríguez A., Sarmiento H., Gutierrez M. Nombres Comunes de las Plantas de Colombia. Universidad Nacional de Colombia. Available from: http://www.biovirtual.unal.edu.co/nombrescomunes/

21. do Nascimento MS, Pina N di PV, da Silva ASB, Gomes LF dos S, de Vasconcellos F, Brandão GC, et al. In vitro antiplasmodial activity and identification, using tandem LC-MS, of alkaloids from Aspidosperma excelsum, a plant used to treat malaria in Amazonia. J Ethnopharmacol. 2019;228:99-109.

22. Roumy V, Ruiz Macedo JC, Bonneau N, Samaillie J, Azaroual N, Encinas LA et al. Plant therapy in the Peruvian Amazon (Loreto) in case of infectious diseases and its antimicrobial evaluation. J Ethnopharmacol. 2020;249:112411.

23. Ortiz R del C. A taxonomic revision of Curarea Barneby \& Krukoff (Menispermaceae). PhytoKeys. 2018;100:9-89.

24. Theplantlist.org [homepage on the Internet]. The Plant List. The Plant List Version 1.1. Available from: http://www.theplantlist.org/

25. United States Pharmacopeial Convention. The United States pharmacopeia: The national formulary. 2016

26. Rodríguez ZJ, Rodríguez YV García JO Arias $M H$, Deharo E Garavito G Comparison of the antimalarial activity of a Colombian traditional Uitoto remedy with laboratory preparations. J Vector Borne Dis. 2020; Ahead of Print DOI: 10.4103/0972-9062.310868

27. Lourenço AM, Faccini CC, Costa CA de J, Mendes GB, Fragata Filho AA Evaluation of in vitro anti-Trypanosoma cruzi activity of medications benznidazole amiodarone hydrochloride, and their combination. Rev Soc Bras Med Trop. 2018;51(1):52-6.

28. de Pilla Varotti F, Botelho ACC, Andrade AA, de Paula RC, Fagundes EMS Valverde $A$, et al. Synthesis. Antimalarial Activity, and Intracellular Targets of MEFAS, a New Hybrid Compound Derived from Mefloquine and Artesunate. Antimicrob Agents Chemother. 2008;52(11):3868-74.

29. Mesia K, Cimanga RK, Dhooghe L, Cos P, Apers S, Totté J, et al. Antimalarial activity and toxicity evaluation of a quantified Nauclea pobeguinii extract. J Ethnopharmacol. 2010;131(1):10-6.

30. Wagner $\mathrm{H}$, Bladt S. Plant drug analysis: a thin layer chromatography atlas Berlin; London: Springer-Verlag; 1996

31. Molyneux DH, Savioli L, Engels D. Neglected tropical diseases: progress towards addressing the chronic pandemic. The Lancet. 2017;389(10066):312-25

32. Izumi E, Ueda-Nakamura T, Veiga-Júnior V, Nakamura C. Toxicity of Oleoresins from the Genus Copaifera in Trypanosoma cruzi: A Comparative Study. Planta Med. 2013;79(11):952-8.

33. Willcox M, Bodeker G, Rasanavo P, editors. Traditional medicinal plants and malaria. Boca Raton: CRC Press; 2004. 431 p

34. Ciccia G, Coussio J, Mongelli E. Insecticidal activity against Aedes aegypti larvae of some medicinal South American plants. J Ethnopharmacol. 2000;72(1-2):185-9.

35. Kloucek P, Svobodova B, Polesny Z, Langrova I, Smrcek S, Kokoska L. Antimicrobial activity of some medicinal barks used in Peruvian Amazon. J Ethnopharmacol. 2007;111(2):427-9.

36. el Kouni MH. Potential chemotherapeutic targets in the purine metabolism of parasites. Pharmacol Ther. 2003;99(3):283-309.

37. Zucca M, Savoia D. Current developments in the therapy of protozoan infections Open Med Chem J. 2011:5:4-10. 
GRAPHICAL ABSTRACT

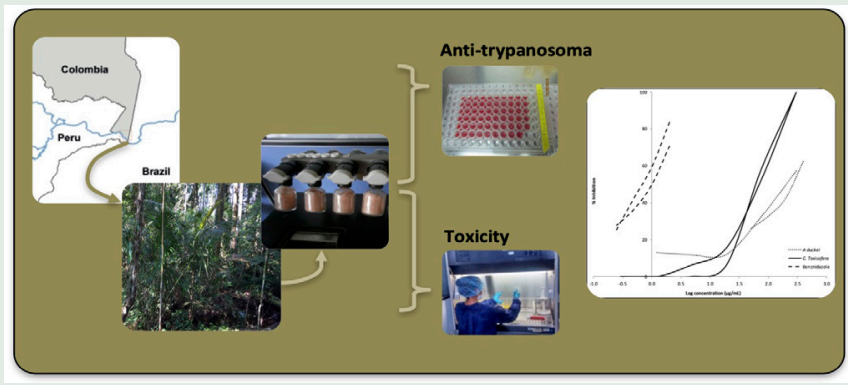

\section{ABOUT AUTHORS}

MH Arias is a nurse, M.Sc. in Pharmacology and PhD Candidate in Pharmaceutical Sciences.

GA Vallejo is Ph.D. and Professor at the Faculty of Sciences, Universidad del Tolima, Colombia.

G Garavito is Ph.D. and Professor at the Pharmacy Department, Faculty of Sciences, Universidad Nacional de Colombia.

\section{SUMMARY}

Chagas disease is the parasitic disease of greatest impact in Latin America; medicinal plants continue to be an affordable front-line option in endemic areas. Since knowledge, uses and attitudes towards this disease are generally absent (because infected people are often unaware of their condition or misdiagnose it), it is not easy to find useful plants directly in traditional knowledge. We assessed, against T. cruzi, promising plants traditionally used to treat other protozoan infections. We aimed to advance in the pharmacological evaluation of four medicinal plants traditionally used in the Amazon against parasitic infections. This experimental pharmacology study, used in vitro biological models of infection and cytotoxicity and, a preliminary phytochemical approach. Plants were collected in the Amazon region of Colombia. The dry plant material was submitted to water percolation extraction. Extracts were tested in vitro against Trypanosoma cruzi (epimastigotes), and cytotoxicity was assessed against HepG2 and MRC5 cells. Finally, the general profile of metabolites present in the extracts was studied by thin-layer chromatography. In vitro concentration-response tests were carried out to obtain $50 \%$ inhibitory and cytotoxic concentrations as a measure of biological activity, estimated from concentration-response curves by regression analysis. Metabolite profiles were evaluated by thin-layer chromatography (TLC). In vitro, against T. cruzi, extracts of Ambelania duckei and Curarea toxicofera displayed concentration-dependent inhibition $\left(\mathrm{IC}_{50}\right.$ of $221+/-29$ and $50+/-5$ $\mu \mathrm{g} / \mathrm{mL}$ respectively), comparable with benznidazole $\left(\mathrm{IC}_{50}: 0.7\right.$ $\mu \mathrm{g} / \mathrm{mL}$ ); while Abuta grandifolia and Aspidosperma excelsum exhibited IC ${ }_{5}$ 's $>500 \mu \mathrm{g} / \mathrm{mL}$. All extracts showed no cytotoxicity against HepG2 and MRC5 cells. Yields of extraction were between 3.2 and $9.5 \%$ and preliminary phytochemical profile showed flavonoids and steroids in all extracts. Promising plants, traditionally used to treat other protozoan infections, could be assessed against $T$. cruzi. C. toxicofera exhibits good activity against epimastigotes of $T$. cruzi, being a species that can reasonably be considered for bioassay-guided antitrypanosomal fractionation.

Cite this article: Arias M, Vallejo GA, Garavito G. Trypanocidal Activity of Traditional Antiparasitic Medicinal Plants from the Amazon. Pharmacog Res. 2021;13(4):227-32. 